\title{
Social Protection During the Covid-19 Pandemic: Time to Rethink Expanding Coverage in Sub-Saharan Africa?
}

\author{
A-R. Mohammed
}

\section{ABSTRACT}

In December 2019, the Covid-19 pandemic erupted in China and quickly spread worldwide. So far, the pandemic has created a twin challenge for governments; an enormous public health crisis and mounting economic decline. Governments to varying degrees have responded to the pandemic using both fiscal and monetary policies. The monetary policy responses from sub-Saharan African (SSA) countries have been piecemeal and incomprehensive. However, estimates suggest that SSA countries might experience the worst economic impacts of the pandemic. Even worse, the region has historically had low levels of social protection coverage. Over the years, calls to expand social protection coverage in the region have been met with resistance on the basis of a supposed lack of affordability. But can SSA countries afford not to expand social protection any longer? The aim of this paper, therefore, is to examine what the Covid-19 might tell us about social protection systems in Africa.

Keywords: Africa, Covid-19, Expansion, Fiscal Space, Social Protection

Published Online: February 7, 2022

ISSN: 2736-5522

DOI: $10.24018 /$ ejsocial.2022.2.1.206

\section{A-R. Mohammed}

University for Development Studies. Faculty of Sustainable Development Studies. Department of Development Management and Policy Studies,

Tamale, Ghana.

(e-mail: mrahim@uds.edu.gh)

\section{INTRODUCTION}

In December 2019, the Covid-19 pandemic emerged in Wuhan (China) and quickly spread worldwide — bringing with it tremendous healthcare and economic costs. To help mitigate the impact of the pandemic on people's lives, various governments have responded with fiscal and monetary policies (International Labor Organization [ILO], 2020a). Sub-Saharan African (SSA) countries have also responded to the pandemic with monetary policies, albeit on a smaller scale and scope compared to industrialized Global North countries. For instance, while the industrialized capitalist countries on average have spent $8 \%$ of their Gross Domestic Product (GDP) on stimulus packages, SSA countries have spent $0.8 \%$ of GDP on stimulus packages (Chowdhury \& Sundaram, 2020).

Even before the Covid-19 pandemic erupted, SSA countries traditionally had low levels of social protection coverage. For example, while Western Europe and Latin America spent 17.98\% and 7.63\% respectively of their GDP on social protection, SSA spent $2.81 \%$ of GDP on social protection in 2012 (World Bank, 2012: 1). A decade ago, Devereux and Lund (2010: 153) described social protection programmes in SSA as '... discretionary, supply-driven, ad hoc interventions ... [that] benefit relatively few vulnerable individuals.' Seven years later in 2017, the reality of under coverage had not improved as the ILO's 2017 World Social Protection Report painted a dismal picture of partial coverage. According to the report, whereas $84.1 \%$ of Europeans and Central Asians were covered, only $17.8 \%$ of Africans had access to social protection (ILO, 2017: xxx). By 2018, these grim statistics of under coverage in SSA had not improved. The United Nations Report on the World Social Situation 2018 notes that although $90 \%$ of Europeans and $60 \%$ of Latin Americans are covered by at least one form of social protection benefit, less than $15 \%$ of SSAs are protected (United Nations, 2018: 10). It is self-evident, therefore, from these bleak statistics that public spending on social protection programmes in SSA and low-income countries are inadequate - even during the pre-pandemic era.

The comparatively low monetary response to the Covid-19 pandemic from SSA governments is troubling, particularly as estimates suggest that the region is likely to bear a disproportionately high economic cost of the pandemic. If we consider the fact that SSA has traditionally had low social protection coverage, the picture that is painted in terms of the effect of the Covid-19 is one of potential mass hunger and human suffering.

While it is evident that social protection coverage in SSA has been low, it is essential to state that even before the pandemic hit, discussions within the international development arena and academic discourses pointed to the need to expand social protection coverage (see Hanlon et al., 2010) without much enthusiasm from SSA governments (Devereux et al., 2010). The counterargument against the calls to scale up the coverage of social protection in SSA has mainly been anchored on a supposed lack of fiscal space (Hanlon et al., 2010). In other words, calls for the expansion of social protection have often been met with the claim 
that social protection programmes in SSA are unaffordable. Accordingly, rather than implement comprehensive social protection systems in the region, piecemeal and selective social protection programmes have been introduced. Against this backdrop and considering the scale and scope of the havoc being wreaked on people worldwide by Covid-19, a unique opportunity has been presented for us to rethink and re-examine the calls to expand social protection programmes in SSA.

The motivation for this paper is based on the author's conviction that while the Covid-19 has brought significant health and economic challenges, it also presents a distinct opportunity and a wakeup call for policymakers and activists to re-echo the calls for a formalization of comprehensive social protection systems in SSA. This paper's aim, therefore, is to examine ex-ante what the Covid-19 pandemic might tell us about social protection in Africa. Apart from this introductory section, the paper is divided into four sections. The next section discusses the trajectory of development policy in SSA, starting with the implementation of structural adjustment programmes in the 1970s to the era of social protection, post-2000. The third section explores the health, but more importantly, the economic impacts of Covid-19 on SSA's large informal sector, within the context of low coverage of social protection. Finally, the fourth section scrutinizes the often-touted resource constraints justification against the implementation of broad-based social protection programmes in SSA. The section further explores the pathways by which SSA countries can create the fiscal space needed to expand social protection coverage. The paper ends by recasting attention away from the fiscal space debate, and towards political will and commitment as the sine qua non for the scaling up of social protection programmes.

\section{From Structural Adjustment to Social Protection: Evolution of Social Protection IN SUB-SAHARAN AFRICA}

During the pre-colonial era, welfare in SSA was provided on a targeted piecemeal basis by mainly religious organisations. Since welfare provision at this time was not comprehensive, Iliffe (1987) notes that people who were not catered for by the missionaries relied on family support or other social networks for assistance. Formal social security systems, on the other hand, were introduced in SSA during the colonial period by the British and the French (Luiz, 2013). However, the welfare programmes introduced by the colonial regimes were specifically designed for the expatriate workers first, and then subsequently expanded to cover the few local urban elites working in the civil service or colonial government (Iliffe 1987; Devereux and Lund 2010). Thus, the delivery of social protection during colonial times was such that most Africans who were not in formal employment were excluded.

Starting in the 1950s, SSA countries underwent political decolonization. Midgley (1997) observes that many SSA countries immediately after independence adopted the welfare regimes they inherited and only marginally increased coverage. However, in terms of social services infrastructure, many governments during the post-independence era — psyched by the ideals of nationalism and the rhetoric of the developmental state - expanded their health care and educational facilities by building modern hospitals and schools to widen access to these services.

\section{A. The Era of Structural Adjustment Programmes}

The 1980s heralded a new direction in terms of the development paths of SSA and low-income countries. Many SSA governments underwent severe economic decline during this period. Subsequently, under the economic stabilization programme christened Structural Adjustment Programme (SAP), the region was ushered into a process of stiff economic austerity and social spending cuts at the behest of the International Monetary Fund (IMF) and the World Bank (WB) (see Killick, 1991; Easterly, 2005). SAPs were externally imposed fiscal policies on SSA and low-income countries ostensibly to halt budget deficits through a series of measures such as privatization, liberalization, and introduction of user-fees in public services (Midgley, 1997).

The 1980s economic crisis and the resultant implementation of SAPs across SSA meant that extensive publicly funded welfare programmes were impossible in the region. During the period of adjustment, the approach to the provision of social protection programmes by states was to focus on designing welfare systems to provide only modest, basic services (Cerami, 2013). Inevitably, this minimalist approach to social protection created a welfare system that protected only a few people in formal employment, leaving out the vast majority of citizens working in rural areas and informal sectors unprotected. Through the implementation of SAP reforms in the 1980s, public provision of basic social services was significantly curtailed. Accordingly, individuals relied on private provision through out-of-pocket payments for services or on social networks such as the family system for support.

Several analyses of the countries that implemented the SAPs reveal deteriorating social conditions. Midgley (1997) and Mkandawire (2001) for instance report that by the 1990s, as a direct consequence of SAPs, basic social services were not being met due to massive retrenchment in health, education, and other social programs, playing out in rising levels of malnutrition, poverty and worsening health outcomes. For instance, the United Nations Children's Fund (UNICEF) in its 1987 Adjustment with a Human Face report 
provided evidence of the effects of adjustment on children's lives in the Global South (Jenson, 2010). Consequently, disenchantment with the poor record of the SAPs in terms of social development in SSA countries engendered a renewed global interest calling for a redirection of development priority away from solely concentrating on fiscal stabilization towards social investment in the late-1990s (Taube, 1993; Barrientos \& Hulme, 2009). In other words, there was a reaffirmation of the efficacy of social policy as an instrument to combat poverty and achieve human development goals (Bradshaw, 2008).

The 1995 World Summit for Social Development in Copenhagen played a central role in bolstering support for the then-emerging consensus on the need for a (re)focus on a human-centered approach to development. In essence, the Copenhagen Declaration on Social Development called for human needs to be placed firmly at the center of development; humans should not only be the means to development but the ends as well (Kwon et al., 2009). More importantly, the United Nations in the 2000 Millennium Declaration equally reaffirmed the need to tackle poverty and other socio-economic inequalities. The Millennium Declaration provided a much wider platform for the global anti-poverty agenda.

\section{B. Social Protection as Development Policy Post-2000 for SSA}

Definitional disagreements about what precisely social protection abound. As such, social protection is understood differently by various agencies and scholars. The Organization for Economic Co-operation and Development defines social protection as 'policies and actions which enhance the capacity of poor and vulnerable people to escape from poverty and enable them to better manage risks and shocks' (OECD, 2009: 12). Ortiz et al. (2019: 2) on the other hand conceptualize social protection as 'a set of policies and programmes designed to reduce and prevent poverty and vulnerability throughout the life cycle'. The 2010 European Report on Development (2010: 1) offers a more comprehensive definition of social protection as:

A specific set of actions to address the vulnerability of people's life through social insurance, offering protection against risk and adversity through life; through social assistance, offering payments and in-kind transfers to support and enable the poor; and through inclusion efforts that enhance the capability of the marginalized to access social insurance and assistance [emphasis in the original].

Together, these definitions of social protection suggest that there are three broad types of social protection programmes: (a) Social Insurance Programmes: examples being disability insurance and contributory pension schemes; (b) Social Assistance Programmes: non-contributory social transfers for tackling income loss and poverty, with examples being cash transfers, child support grant, and old-age benefits, and (c) Minimum Labor Standards: government legislation on minimum labor standards.

Jointly, these three categories of social protection programmes provide protective, preventive, promotive, and transformative functions (Devereux \& Sabates-Wheeler, 2004: 9; OECD, 2009). Social assistance programmes provide protection from poverty and loss of income, while social insurance programmes prevent deprivation. Promotive social protection programmes build peoples' resilience and enhance their livelihoods, whereas transformative social protection programmes promote social cohesion by addressing issues of discrimination against the disabled and vulnerable. Thus, these four functions highlight the critical role of social protection programmes in improving human welfare. Almost describing social protection as a magic bullet, the United Nations (2018: 1) notes that 'no country has been able to reduce poverty and improve living conditions on a broad scale without putting comprehensive social protection systems in place.' While this might seem like a generalization, it nonetheless underscores the key role social protection programmes play in achieving pro-poor growth.

After years of implementing SAPs (and due to its resultant retrenchment of welfare and social spending in SSA in the 1970s and 1980s), social protection emerged as the new development orthodoxy at the turn of the millennium. Importantly, the acknowledgement that social protection has an indispensable role to play in the development policy of low-income countries was a marked paradigmatic shift. For, although social protection programmes had been in existence for decades in developed countries, it was often argued that social protection programmes were not suitable for low-income countries (Merrien, 2013). Social assistance programmes, particularly cash transfers, were perceived as rights in developed countries but luxuries in low-income countries since it was argued that low-income countries could not afford it (Holzmann et al., 2003; Hanlon et al., 2010; Chitonge, 2012).

Nevertheless, as already highlighted, due to the human, social and economic costs of the implementation of the SAPs, at the turn of the millennium, the view that social protection programmes were an ill-suited luxury for low-income countries was no longer tenable. Subsequently, social protection programmes were implemented and expanded across SSA countries. For instance, Niño-Zarazúa and colleagues (2012) observe a general pattern of SSA countries implementing social transfer programmes at the turn of the Millennium that aimed at improving the education, health, and nutrition of children. Zambia in 2004 established the Social Cash Transfer Scheme that offers monthly cash payments to households with children and orphans; Sierra Leone in 2007 also established the Social Safety Net Program to offer incentives to families with children to enhance education; while in 2008, Ghana also created the Livelihood Empowerment Against Poverty - a conditional cash transfer programme that seeks to encourage school 
enrolment and improve child poverty rates (Niño-Zarazúa et al., 2012). Similarly, Luiz (2013: 116) reports that South Africa provides a Child Support Grant programme to millions of beneficiary households. Nonetheless, as the titles of these programmes suggest, the post-2000 expansion of social protection programmes in SSA tended to focus on addressing child poverty in poor families or were targeted social safety nets in general, rather than implementing comprehensive universal welfare systems.

In other words, despite the post-2000 welfare expansion in SSA, limited social security coverage is still the norm in SSA. Non-contributory social security systems are still underdeveloped in SSA (Luiz, 2013). Social transfers schemes (particularly cash transfers usually targeted at children) are the most widespread social protection programmes. Due to factors such as a lack of political will and commitment and weak institutional capacity, comprehensive social security systems are currently non-existent in SSA (Devereux \& Cipryk, 2009; Chitonge, 2012).

\section{COVID-19: A Global PANDEMIC In THE CONTEXT OF Low Social Protection CoveragE IN SSA}

As already stated, in December 2019, the Covid-19 pandemic plunged the world into a public health crisis. Starting in the Wuhan city of China, the highly contagious virus quickly spread worldwide (Du Toit, 2020; Johnson \& Roberto, 2020), eventually reaching Africa in February 2020 (Africa News 2020). Described as the 'worst global crisis since the Second World War' (ILO, 2020b: 2), the pandemic to date has had significant health and economic impacts for countries, leaving governments scrambling to address the crisis (Johnson \& Roberto, 2020).

The challenges presented by the Covid-19 pandemic are mainly twofold: a healthcare crisis and a global economic meltdown. The healthcare impact of the virus has been overwhelming. According to the Johns Hopkins Hospital (2020), as of 17 July 2020, 14 million people worldwide had tested positive for the Covid19 pandemic. By November 17, 2020, the number of infections had spiked dramatically to 54 million reported cases, with 1.3 million deaths (World Health Organization [WHO], 2020). Due to the sheer scale of the number of infections, health facilities in Italy, Spain, China, and the UK were quickly overwhelmed (Johnson \& Roberto, 2020), stretching hospital staff and equipment to limits never imagined possible. It is important to stress that while these numbers are depressing, the Covid-19 pandemic is a rapidly evolving pandemic, as such, these numbers might get worse over time.

The economic impacts of the Covid-19 pandemic have been far-reaching, too. Due to the speed and ease of the transmission of the virus, governments worldwide quickly implemented lockdowns — preventing people from leaving their homes, limiting mass gathering, schools and work closures, grounding public transportation systems - in hope of curtailing the spread of the virus (Johnson \& Roberto, 2020; Dafuleya, 2020; Hargreaves \& Logie, 2020). However, lockdowns and restrictions on people's movements have meant two things generally: slowed economic activity, and, relatedly, mass unemployment (OECD, 2020). As companies have declared bankruptcies due to slowed economic activities (Johnson \& Roberto, 2020), millions of people have either lost their jobs or are receiving lower wages. For instance, the ILO (2020b) estimates that 2.7 billion workers have been impacted by the Covid-19 virus, through the receipt of lower wages. Out of this figure, 1.6 billion workers in the informal sector have been the most severely impacted by the implementation of lockdown regimes (ILO, 2020b).

An important policy option that has been championed by the ILO and other international agencies to help deal with the economic impacts of the Covid-19 pandemic has been the implementation of new social protection programmes, or the extension of social protection programmes to cover previously excluded people (Ebuenyi, 2020). Accordingly, while implementing strict lockdown regimes, governments have introduced different stimulus packages and social protection programmes - particularly social assistance programmes - to help cushion businesses, individuals and households against the economic challenges created by the pandemic (Ebuenyi, 2020).

Generally, the social assistance programmes that have been introduced are mainly cash transfers and social security benefits (Chowdhury \& Sundaram, 2020). In the USA, the government approved a $\$ 2$ trillion stimulus package to families and businesses (Johnson \& Roberto, 2020), while the Irish government approved a $€ 350$ per week Covid-19 Pandemic Unemployment Payment programme. Broadly, therefore, in the Global North contexts, non-contributory social protection programmes, in the form of social assistance programmes have thus far, played a critical role in helping people cope with the economic impacts of the Covid-19 pandemic.

\section{A. Sub-Saharan Africa's Covid-19 Response}

In terms of the health impacts of the Covid-19 pandemic, the SSA region has been less hit, compared to countries in the Global North. In comparison with countries in the Global North, fewer people have either contracted the virus or died as a result of the Covid-19 pandemic in SSA, leaving public health experts and virologists baffled (see Njenga et al., 2020). For instance, Chitungo et al. (2020) note that whereas 10 million people in America and 3 million in Europe were infected as of 9 August 2020, Africa had 1 million 
cases by then. By November 24, 2020, the total number of infections and deaths in the USA was six times higher than the numbers in Africa, although Africa's population exceeds 1 billion people, compared to the USA's population of about 320 million. As of November 2020, 12 million people in America had been affected by the Covid-19, with 255000 deaths (WHO, 2020), compared to 2 million infections and 50,000 deaths in Africa (BBC, 2020). Thus, in terms of its health impacts, the Covid-19 has so far not been as critical in SSA.

Conversely, the economic impacts of Covid-19 have been rather consequential. It is estimated that economic growth in rates in Africa might decline to between $-2 \%$ and $-5 \%$, compared to an average growth rate of 2.4\% in 2019 (DW Africa, 2020). The inevitable effect of negative growth rates is job losses. It is estimated that about 20 million people will lose their jobs in Africa, due to the sharply declining economic growth rates (African Union, 2020). The implementation of strict lockdown regimes and the concomitant closure of businesses have particularly hit Africans the hardest for a reason. Africa has a large informal sector (Ebuenyi, 2020). Estimates suggest that the informal sector employs about $86 \%$ of workers in Africa (ILO 2018). Workers in the informal sector typically work as domestic workers, street vendors, daily labourers who 'live from hand to mouth', thus, 'disrupting their activities by even a day could mean food deprivation' (Dafuleya, 2020: 254). Africa's informal sector workers cannot cope with lockdowns and social distancing orders without severe consequences to their lives and incomes (United Nations, 2020).

Therefore, the implementation of lockdowns in SSA implies that many 'household earners would be forced to choose between the virus and putting food on the table' (United Nations, 2020: 14). Complicating this further is the fact that $90 \%$ of the women who are employed in Africa work in the informal sector (United Nations, 2020). In this case, households that are headed by women are particularly at risk — with potential ripple effects on children. Therefore, a regime of lockdowns will only bring untold hardships to a disproportionately large number of poor and vulnerable Africans, especially.

While the economic impacts of the pandemic have been particularly dire for SSA, the monetary and fiscal responses from SSA governments have not been as broad-based in terms of coverage, compared to the fiscal and monetary responses in the Global North. Although data on the extent of the economic and social impacts of the pandemic is still scant and evolving (Ossome, 2020), compared to other regions, SSA has the lowest Covid-19 related stimulus spending. While industrialized capitalist countries on average have spent $8 \%$ of GDP on stimulus packages, SSA has spent $0.8 \%$ of their GDP on stimulus packages (Chowdhury \& Sundaram, 2020). Furthermore, of the $\$ 10.6$ trillion spent in fiscal and monetary measures as a response to the Covid-19 pandemic by September 3rd 2020, just $0.06 \%$ of this amount was spent in low-income and SSA countries (ILO, 2020a).

The examples in the Global North suggest that countries with robust and efficient social protection systems before the crisis hit are more able to react to the consequences of Covid-19, either by increasing social protection coverage or benefits size (ILO, 2020c). Conversely, countries without strong social protection systems are less about to respond to the pandemic swiftly and effectively. Strong and efficient welfare systems are uncommon in Africa, as the majority of Africans have to depend on family and other non-state networks and actors in times of shocks and crisis (Kavagnah et al., 2020; Dixon, 2016). The low public spending on the Covid-19 pandemic related social programmes in Africa is a reflection of the generally piecemeal and target nature of social protection provision in the region.

\section{What Routes to EXPANDING SOCIAL PROTECTION IN SSA?}

Debates about the need to expand social protection coverage in SSA have been dated and well documented. The main theoretical resistance to the calls for expanding social protection coverage in SSA has been the cost constraint argument that SSA countries do not have the fiscal space to expand social protection (Chitonge, 2010). Nonetheless, Ortiz et al. (2019) note that while some analysts have claimed that expanding social protection coverage in SSA is impractical because that will create significant budget deficits in public finances, implementing broad-based social protection programmes is actually both feasible and desirable, as social protection programmes are investments.

Social protection spending is an investment because it has positive impacts on citizens and the state. The ILO (2016) affirms this by arguing that public spending on social protection programmes is an investment because social protection programmes directly lead to poverty reduction and increased consumption and afford citizens better access to nutritious food and improved health care utilization. Social protection programmes also lead to higher school attendance for pupils within marginalized contexts especially. Social protection programmes, therefore, contribute to preventing poverty by increasing the resilience of households and individuals to economic and health shocks (ILO, 2016). Together, all these benefits ultimately lead to inclusive growth and increased human development and productivity for the state.

Indeed, simulations, affordability models and alternative policy recommendations done by experts show that expanding social protection coverage even in low-income countries is possible (Pal et al., 2005; Hagemejer, 2009; ILO, 2020a). One of such studies is Ortiz et al.'s (2019) piece on Fiscal Space for Social Protection: A Handbook for Assessing Financing Options. They show from their study that there are as 
many as eight practical alternative ways of either creating or increasing the fiscal space needed to expand social protection coverage in low-income countries (Ortiz et al., 2019). First, Ortiz et al. (2019) argue that SSA and low-income countries can expand social protection programmes by increasing their tax revenue. This is a particularly important point, as SSA has the lowest tax-to-GDP ratio at $13.4 \%$ in 2018, compared to $25 \%$ in Europe, and $18 \%$ in Latin America (Economic Commission for Africa, 2020). Expanding the tax net to include actors and economic activities in the informal sector, for example, is a viable means of creating the fiscal space for increased government spending on social protection. Second, SSA can reallocate public spending from other non-pressing avenues such as military spending, to widen the coverage of social protection programmes. SSA countries might also consider restructuring their public debts to free up the fiscal space for social protection. In many cases, debt-repayment as a percentage of government revenue is quite high, leaving these countries with little fiscal space to spend on social programmes. Additionally, low-income countries can use their central bank's foreign exchange reserves, which normally is piled up in anticipation of unforeseen expenditures. Also, the international donor community, cognizant of the critical role social protection plays, might be implored by SSA governments to increase their Overseas Development Assistance. Finally, Ortiz et al. (2019) suggest that combating corruption and illicit financial flows — both of which are pervasive in SSA and low-income countries can also provide the needed fiscal space and resources to scale up the coverage of social protection programmes.

These eight alternative funding sources are a practical means of creating the needed fiscal space for increased social protection spending. Admittedly, these suggestions about funding alternatives are not easy to implement, as a strong political will and commitment are required. Thus, more than a lack of fiscal space, what SSA and low-income countries need more is the political will and commitment (Chitonge, 2012; Ortiz et al., 2019) to make the tough decisions to implement these alternative funding suggestions. Reiterating the primacy of political will in the quest to expand social protection across SSA, the African Union's Commissioner of Social Affairs argued:

It is clear that cost is not a major factor for not establishing Social Protection and transfer programmes. National social transfer programmes are affordable if the political will exists, and also, if additional funding received by international development partners is utilized to scale up the social transfer programmes (Gawanas, 2006). Effectively tackling corruption and tax evasion, widening the tax base by introducing new taxes, for example, are hard decisions that require a strong political will, not least because the implementation of these revenue mobilization policies is likely to receive strong opposition and resistance (Ortiz et al., 2019).

Finally, the Covid-19 pandemic is both an opportunity and a wake-up call for African governments and policymakers to rethink their commitment to the expansion of social protection. The long-term health and economic effects of the Covid-19 pandemic portend grim possibilities for Africa. Early simulation models by Morsy et al. (2020) show that if the effects of the coronavirus pandemic are not addressed, particularly the economic impacts, many Africans are likely to fall into extreme poverty and move further away from achieving the Sustainable Development Goals of eliminating poverty by 2030. Covid-19 in the worst-case scenario could push 29 million Africans below the extreme poverty line of $\$ 1.90$ per day (Economic Commission for Africa, 2020). Therefore, a failure to respond appropriately to the economic impacts of Covid-19 is likely to lead to significant job losses, mass unemployment, loss of income, food insecurity, widespread deprivation, and, consequently, derail human progress.

This grim reality of the potential human cost of the pandemic is particularly troubling, bearing in mind the significant human costs SSA countries had to bear under the implementation of structural adjustment programmes in the 1970s and 1980s. Modest human capital investments have been realised, following the introduction of social protection (albeit piecemeal and limited) post-2000. The lack of sufficient policy responses to Covid-19 in SSA, in the context of a potential return to austerity worldwide after the pandemic, raises genuine fears that the pandemic could lead to wiping out years of progress in poverty reduction and human development in SSA (Sumner et al., 2020). In a sense, therefore, the low coverage of social protection during the pre-crisis period, plus the effects of lockdowns within a general context of limited fiscal and monetary response to the pandemic in SSA are unique challenges that can undermine the modest progress of human development post-SAPs.

The need for social protection programmes becomes especially critical during times of crisis as inaction to protect the poor and vulnerable risks not only a significant increase in poverty in the wake of crisis but also has wider implications well after the crisis (Ravallion, 2008). Inadequate or failed response to a crisis will have deeper and lasting impacts on their citizens' lives (Ravallion, 2008). More importantly, apart from the need to protect the poor and vulnerable during a crisis, as low and inadequate as the social protection programmes in SSA are, the use of ad hoc short-term and piecemeal social protection programmes is unlikely to be of any consequence during the crisis and beyond. What is needed in SSA are comprehensive national social security systems, which are protected fiscal contraction policies such as austerity (ILO, 2020a). 


\section{CONCLUSION}

Historically, SSA countries, on the whole, have been without comprehensive social security programmes. For decades, calls to expand the coverage of social protection in Africa were met with strong resistance anchored on the seemingly compelling resource constraints arguments. Accordingly, rather than implementing comprehensive social protection systems in SSA, the norm has been the institutionalization of piecemeal, ad hoc, and targeted social protection systems, leaving millions without protection or coverage. The Covid-19 pandemic is a wake-up call for African countries to (re)focus on investing in their health and social protection systems to help contain or mitigate crises and shocks. Pulling the lack of resources card as a counter to the calls for expanded social protection systems is no longer tenable. Considering the scale of the economic impact of the Covid-19 pandemic in SSA, African governments must not allow suffering and deprivation of a severe scale and scope, due to their inaction to respond adequately to the Covid-19 pandemic. The human and social cost of Covid-19 would be too great to reverse. Although many have argued that expanding special protection programmes in SSA is unaffordable, various simulations and models have shown that expanding social protection coverage even in low-income countries is possible, as long as there is the political will and commitment to take the hard decisions of exploring alternative funding options such as combating illicit money flows and corruption or realigning public expenditure among others.

\section{FUNDING}

Author did not receive funding for this article.

\section{REFERENCES}

African Union. (2020). 'Impact of the coronavirus (COVID-19) on the African economy'. Available at: https://www.tralac.org/documents/resources/covid-19/3218-impact-of-the-coronavirus-covid-19-on-the-african-economyafrican-union-report-april-2020/file.html.

Africa News. (2020). 'Coronavirus in Africa'. Available at: https://www.africanews.com./2020/04/04/ coronavirus-in-africabreakdown-of-infected-virus-free-countries/.

Barrientos, A., \& Hulme, D. (2009). Social protection for the poor and poorest in developing countries: reflections on a quiet revolution: commentary. Oxford Development Studies, 37(4), 439-456.

BBC. (2020). 'Coronavirus: What's happening to the numbers in Africa?' Available at: https://www.bbc.com/news/world-africa53181555.

Bradshaw, S. (2008). From structural adjustment to social adjustment: a gendered analysis of conditional cash transfer progra mmes in Mexico and Nicaragua. Global Social Policy, 8(2), 188-207.

Cerami, A. (2013). Permanent Emergency Welfare Regimes in Sub-Saharan Africa: The Exclusive Origins of Dictatorship and Democracy. London: Palgrave Macmillan.

Chitonge, H. (2012). Social Protection Challenges in Sub-Saharan Africa: "Rethinking Regimes and Commitments." African Studies, 71(3), 323-345.

Chitungo, I., Dzobo, M., Hlongwa, M., and Dzinamarira, T. (2020). COVID-19: Unpacking the low number of cases in Africa. Public Health in Practice 1: 100038. doi:https://doi.org/10.1016/j.puhip.2020.100038.

Chowdhury, A., \& Sundaram, J.K. (2020). Reviving the Economy, Creating the 'New Normal'. Available at: http://www.ipsnews.net/2020/06/reviving-economy-creating-new-normal/.

Dafuleya, G. (2020). Social and Emergency Assistance Ex-Ante and During COVID-19 in the SADC Region. The International Journal of Community and Social Development, 2(2), 251-268. doi:10.1177/2516602620936028.

Devereux, S., \& Cipryk, R. (2009). Social Protection in Sub-Saharan Africa: A Regional Review. Centre for Social Protection. Brighton: Institute of Development Studies.

Devereux, S., Davis, M., McCord, A., Slater, R., Freelad, N., Ellis, F. and White, P. (2010). Social Protection in Africa: Where Next? Discussion paper.

Devereux, S., \& Lund, F. (2010). Democratising Social Welfare in Africa. In V. Padayachee (Ed), The Political Economy of Africa $\left(1^{\text {st }}\right.$ ed., pp. 152-172). Routledge.

Devereux, S., \& Sabates-Wheeler. (2004). Transformative Social Protection. Institute of Development Studies Working Paper 232. Available at: https://www.unicef.org/socialpolicy/files/Transformative Social_Protection.pdf.

Dixon, J. (2016). Social welfare in Africa. Abingdon: Routledge.

Du Toit, A. (2020). Outbreak of a novel coronavirus. Nature Reviews Microbiology, 18(3), 123. doi: 10.1038/s41579-020-0332-0.

DW Africa. (2020). World Bank: no African country can face this crisis alone. Available at: https://www.dw.com/en/world-bankno-african-country-can-face-this-crisis-alone/a-53142901.

Easterly, W. (2005). What did structural adjustment adjust? Journal of Development Economics, 76(1), 1-22.

Ebuenyi, I.D. (2020). COVID-19: an opportunity for African governments to rethink social welfare benefits and protection. The Pan African Medical Journal, 35(Supplement 2). doi: 10.11604/pamj.supp.2020.35.2.23875.

Economic Commission for Africa. (2020). COVID-19 in Africa: Protecting lives and Economies. Available at: https://www.uneca.org/publications/covid-19-africa-protecting-lives-and-economies.

European Report on Development. (2010). Social Protection for Inclusive Development: A New Perspective in EU Co-operation with Africa. San Domenico di Fiesole: European University Institute. Available at: https://ec.europa.eu/europeaid/policies/research-development/research/european-report-development-2010-social-protectioninclusive_en. 
Gawanas, B. (2006). Investing in People to Promote Growth and Stability: Building the Links Between Social Policy and Basic Social Protection to African Economic and Growth Policy. A keynote address delivered at the African Union Intergovernmental Regional Workshop on Social Protection. Livingstone, Zambia, March 21-23.

Hagemejer, K. (2009). Can Low Income Countries Afford Basic Social Security? Promoting Pro-Poor Growth: Social Protection. OEDC.

Hanlon, J., Barrientos, A., \& Hulme, D. (2010). Just Give Money to The Poor: The Development Revolution from The Global South. Sterling: Kumarian Press.

Hargreaves, J.R. \& Logie, C.H. (2020). Lifting lockdown policies: A critical moment for COVID-19 stigma. Global Public Health, 15(12), 1917-1923. doi:10.1080/17441692.2020.182577.

Holzmann, R., Sherburne-Benz, L. \& Tesliuc, E. (2003). Social Risk Management: The World Bank's Approach to Social Protection in a Globalising World. Available at: http://citeseerx.ist.psu.edu/viewdoc/download?doi=10.1.1.179.625\&rep=rep1\&type=pdf.

Hopkins University, J. (2020). COVID-19's historic economic impact. The U.S. and abroad. Available at: https://hub.jhu.edu/2020/04/16/coronavirus-impact-on-european-american-economies/.

ILiffe, J. (1987). The African Poor: A History. New York: Cambridge University Press.

International Labor Organization. (2016). Developmental Impacts of Expanding Social Protection. Geneva.

International Labor Organization. (2017). World Social Protection Report: Universal Social Protection to Achieve the Sustainable Development Goals 2017-19. Available at: https://www.ilo.org/wcmsp5/groups/public/---dgreports/---dcomm/--publ/documents/publication/wcms_604882.pdf.

International Labor Organization. (2018). Women and men in the informal economy: A statistical picture. Available at: https://www.ilo.org/global/publications/books/WCMS_626831/lang--en/index.htm.

International Labor Organization. (2020a). Financing gaps in social protection: Global estimates and strategies for developing countries in light of the COVID-19 crisis and beyond. ILO Brief: Social Protection Spotlight. https://www.ilo.org/secsoc/information-resources/publications-and-tools/Brochures/WCMS 755475/lang--en/index.htm.

International Labor Organization. (2020b). COVID-19 and the world of work. Updated estimates and analysis. ILO Monitor. https://www.ilo.org/wcmsp5/groups/public/---dgreports/---dcomm/documents/briefingnote/wcms 743146.pdf.

International Labor Organization. (2020c). Social protection responses to the COVID-19 crisis: Country responses and policy considerations. ILO Brief. Social Protection Spotlight. https://www.ilo.org/secsoc/information-resources/publications-andtools/Brochures/WCMS_742337/lang--en/index.htm.

Jenson, J. (2010). Diffusing ideas for after neoliberalism: The social investment perspective in Europe and Latin America. Global Social Policy, 10(1), 59-84.

Johnson, A.F., \& Roberto, K.J. (2020). The COVID-19 pandemic: Time for a universal basic income?' Public Administration and Development, 40(4), 232-235.

Kasahara, S. (2013). The Asian Developmental State and the Flying Geese Paradigm. UNCTAD Discussion Paper No 213.

Kavanagh et al. (2020). Access to lifesaving medical resources for African countries: COVID-19 testing and response, ethics, and politics. The Lancet, 395(10238), 1735-1738.

Killick, T. (1991). Problems and Limitations of Adjustment Policies. London: Overseas Development Institute.

Kwon, H.-j., Mkandawire, T., \& Palme, J. (2009). Introduction: social policy and economic development in late industrializers. International Journal of Social Welfare, 18: S1-S11.

Luiz, J. M. (2013). A Review of Social Welfare in Sub-Saharan Africa: From the Colonial Legacy to the Millennium Development Goals. Economic Papers, 32(1), 110-210.

Merrien, F.X. (2013). Social protection as development policy: A new international agenda for action. International Development Policy| Revue internationale de politique de développement, 4(4.2): 89-106.

Midgley, J. (1997). Social Welfare in Global Context. New Delhi: Sage.

Mkandawire, T. (2001). Thinking about developmental states in Africa. Cambridge Journal of Economics, 25(3), $289-314$.

Morsy, H., Balma, L., \& Mukasa, A.N. (2020). Not a Good Time: Economic Impact of COVID-19 in Africa. Working Paper Series $N^{\circ} 338$, African Development Bank, Abidjan, Côte d'Ivoire. https://www.afdb.org/fr/documents/working-paper-338-not-goodtime-economic-impact-covid-19-africa.

Niño-Zarazúa, M., Barrientos, A., Hickey, S., \& Hulme, D. (2012). Social Protection in Sub-Saharan Africa: Getting the Politics Right. World Development, 40(1), 163-176.

Njenga, M. K., Dawa, J., Nanyingi, M., Gachohi, J., Ngere, I., Letko, M., Otieno, C. F., Gunn, B. M., \& Osoro, E. (2020). Why is There Low Morbidity and Mortality of COVID-19 in Africa? The American Journal of Tropical Medicine and Hygiene, 103(2), 564-569.

Organization for Economic Co-operation and Development (OECD). (2020). Evaluating the initial impact of COVID-19 containment measures on economic activity. http://www.oecd.org/coronavirus/policy-responses/evaluating-the-initial-impactof-covid19-containment-measures-on-economic-activity-b1f6b68b/.

Ortiz, I., Chowdhury, A., Duran-Valverde, F., Muzaffar, T., \& Urban, S. (2019). Fiscal Space for Social Protection: A Handbook for Assessing Financing Options. Geneva: ILO. https://www.ilo.org/secsoc/information-resources/publications-andtools/books-and-reports/WCMS_727261/lang--en/index.htm.

Ossome, L. (2020). The care economy and the state in Africa's Covid-19 responses. Canadian Journal of Development Studies, $42(1-$ 2), 68-78.

Pal, K., Behrendt, C., Le'ger, F., Cichon, M., \& Hagemejer, K. (2005). Can Low-Income Countries Afford Basic Social Protection? First Results of a Modeling Exercise. Issues in Social Protection Discussion Paper, 13. Geneva: International Labour Office.

Ravallion, M. (2008). Bailing out the World's Poorest. The World Bank. Available at: https://openknowledge.worldbank.org/handle/10986/6288.

Sumner, A., Hoy, C., \& Ortiz-Juarez, E. (2020). Estimates of The Impact of Covid-19 On Global Poverty. WIDER Working Paper 2020/43, Helsinki: UNU-WIDER.

Taube, G. (1993). Social Dimensions of Adjustment (SDA): Conceptual Issues and Empirical Evidence from Tanzania and Other African Countries. Africa Spectrum, 28(2), 165-183.

United Nations. (2018). Promoting Inclusion through Social Protection: The Report on the World Social Situation 2018. Available at: https://www.un.org/development/desa/dspd/wp-content/uploads/sites/22/2018/07/1-1.pdf.

United Nations. (2020). Impact of COVID-19 in Africa. Policy Brief. Available at: https://www.uneca.org/publications/policy-briefimpact-covid-19-africa.

World Bank. (2012). Affordability and Financing of Social Protection Systems. World Bank Africa Social Protection Policy Briefs.

World Health Organization. (2020). WHO Coronavirus Disease (COVID-19) Dashboard. Available at: https://covid19.who.int/. 